NBER WORKING PAPER SERIES

\title{
POLITICAL IDEOLOGY AND ENDOGENOUS TRADE POLICY: AN EMPIRICAL INVESTIGATION
}

\author{
Pushan Dutt \\ Devashish Mitra \\ Working Paper 9239 \\ http://www.nber.org/papers/w9239
NATIONAL BUREAU OF ECONOMIC RESEARCH
1050 Massachusetts Avenue
Cambridge, MA 02138
October 2002

We are indebted to Lawrence Broz, Marc Busch, Gary Engelhardt, Robert Feenstra, Jeffry Frieden, Gordon Hanson, Cem Karayalcin, Philip Levy, Will Martin, Matthew Slaughter, Connie Smith, and Dimitrios Thomakos for valuable comments and suggestions. We also thank seminar audiences at Baruch College, the Canadian Economic Meetings (2002, Calgary), NBER Summer Institute 2002, Syracuse University, the University of Alberta, the University of Calgary, the World Bank, and Yale University for useful discussions. The views expressed herein are those of the authors and not necessarily those of the National Bureau of Economic Research.

(C) 2002 by Pushan Dutt and Devashish Mitra. All rights reserved. Short sections of text, not to exceed two paragraphs, may be quoted without explicit permission provided that full credit, including (C) notice, is given to the source. 
Political Ideology and Endogenous Trade Policy: An Empirical Investigation

Pushan Dutt and Devashish Mitra

NBER Working Paper No. 9239

October 2002

JEL No. F10, F11, F13

\section{ABSTRACT}

In this paper, we empirically investigate how government ideology affects trade policy. The prediction of a partisan, ideology-based model (within a two-sector, two-factor Heckscher-Ohlin framework) is that left-wing governments will adopt more protectionist trade policies in capital rich countries, but adopt more pro-trade policies in labor rich economies than right-wing ones. The data strongly support this prediction in a very robust fashion. There is some evidence, that this relationship may hold better in democracies than in dictatorships though the magnitude of the partisan effect seems stronger in dictatorships.

\author{
Pushan Dutt \\ Department of Economics \\ University of Alberta \\ Edmonton, Alberta \\ CANADA T6G 2H4 \\ pdutt@ualberta.ca
}

\author{
Devashish Mitra \\ Department of Economics \\ The Maxwell School of Citizenship \& \\ Public Affairs \\ Syracuse University \\ 133 Eggers Hall \\ Syracuse, NY 13244 \\ and NBER \\ dmitra@maxwell.syr.edu
}




\section{Introduction}

Political ideology has been conceptualized in a number of ways giving rise to a multiplicity of meanings and interpretations. One view is that it stands for the self-defined notions of public interest and altruistic goals of politicians and political parties, which form the basis for most of economic policy making. ${ }^{1}$ Another view is that the interests of constituents and ideological preferences of politicians are interrelated, with the former probably determining the latter. ${ }^{2}$ However, in between these two extremes, is the position that pure altruistic, public-interest motivations as well as constituents' interests are both important in determining the ideological positions taken by political parties and politicians. ${ }^{3}, 4$

In this paper, we investigate how trade policy depends on the political ideology of the government (the party or the ruler in power). We look at how trade policy varies with the extent of the government's leftist (pro-labor, as opposed to pro-capital) orientation. Our analysis is independent of which of the above definitions of ideology one adopts. In other words, a left-wing party adopts a pro-labor stance either because its constituents are workers whose support it needs in terms of votes and political contributions, and/or they really place a high weight on egalitarianism. Similarly, a right wing party might be taking care of their constituents, the capitalists, and/or may truly believe in providing incentives for capital accumulation to foster growth and generate

\footnotetext{
1 This view has been held by Kau and Rubin (1979) and Kalt (1981). They find support for this view in their empirical studies that show that congressional voting behavior can be explained primarily by such "ideological" orientations rather than the economic interests of constituents.

2 See Peltzman (1984). He finds empirical support for this position using Senate voting records across a wide range of issues. Alt (1986) writes: “...class-party modelers from Kalecki to Hibbs say,...parties are policy-oriented, ideological agents of their supporters..."

${ }^{3}$ Kalt and Zupan (1984), define ideology as a set of normative statements that describe the best or most preferred states of the world (in an altruistic and moralistic sense). Econometrically separating the effects of pure 'ideology' and the constituents' interests in Senate voting (on strip-mining controls), they find both to be fairly important empirically.

4 There is also an informational aspect to ideology - a candidate can succinctly state her position on a host of issues by presenting her views on all issues in simple one-dimesional terms (left vs. right, or liberal vs. conservative for instance). Glazer and Grofman (1989) show that in the presence of imperfect information (less than fully informed voters) a candidate who uses ideology merely as a label can often defeat a candidate who tries to specify her position on each of the issues that defy any single ideological label. While a fully informed electorate would presumably see a majority preferring the second candidate, costly information acquisition could see the former victorious with ideology providing a default position on every possible issue. According to Arthur Downs (1957) as well, ideology is a platform or position(s) adopted by parties seeking office and an efficient way for politicians to summarize their position on a host of issues.
} 
jobs. In our analysis, we just assume that a government that is more left-oriented places a higher weight on the welfare of workers relative to that of capitalists, which can be consistent with any or all of the above reasons. This is consistent with the findings of Hibbs (1977) who showed in his empirical investigation of 14 major industrialized countries that countries with left-wing governments had lower unemployment and higher inflation than others. He reaches similar conclusions from the time series analysis of US and UK data. ${ }^{5}$ This is consistent with his "partisan theory" according to which politicians are "partisan" - left-wing and right-wing governments have different objective functions, the former attributing a higher cost to unemployment relative to inflation than the latter. Alesina (1987) develops his "rational partisan theory" using a two-party model in which the left-wing party attaches a higher weight to unemployment relative to inflation (and a higher target inflation rate) in its loss function than the right-wing party. ${ }^{6}$ Hibbs and Vasilatos (1982) and Hibbs, Rivers and Vasilatos (1982), in different studies of survey data for the US and UK, show that the electorate's preferences and concerns about macroeconomic issues are classrelated, with blue-collar groups relatively more concerned about unemployment and white-collar groups more concerned about inflation. ${ }^{7}$ Magee, Brock and Young (1989) have also argued that the low unemployment-high inflation combination under Democratic presidents benefits workers (debtors) while the opposite combination under Republican presidents benefits capitalists (creditors). ${ }^{8}$ Thus, it is fairly standard in the political economy literature to use left-wing (right-wing)

\footnotetext{
${ }^{5}$ Also, see Alt (1985) who analyzes data from 14 western industrial nations between 1960 and 1983 and finds that unemployment falls (rises) following a change from a right-wing (left-wing) to a left wing (right-wing) government. In arriving at this conclusion, Alt has to control for the constraint imposed by the world level of economic activity.

${ }^{6}$ Alesina and Roubini (1992) find empirical support for the rational partisan model using OECD data.

${ }^{7}$ For the US, they calculate the marginal rate of substitution between inflation and unemployment for blue-collar workers to be 1.5 and for white-collar workers to be 2.2. In other words, in order to maintain a given level of the political approval index for blue-collar workers, a 1 percentage point increase in the inflation rate would have to be accompanied by a decrease of about 1.5 percentage points in the unemployment rate while for white-collar workers, this number is 2.2 percentage points of unemployment. Thus, blue-collar workers do not care much about inflation, but care a lot more about unemployment. Therefore a small reduction in unemployment is enough to compensate them for any given increase in inflation. They find qualitatively similar results for the UK. In fact, for the UK, they also find that, even after controlling for variations in responses to economic outcomes of governments under different parties, manual working-class voters are far more supportive of Labor governments than Conservative governments.

8 This is the standard textbook argument in macroeconomics that a sudden increase in the inflation rate benefits debtors at the expense of creditors, since the former will be paying back the latter a smaller amount of money in real terms.
} 
and pro-labor (pro-capital) interchangeably when describing political parties. ${ }^{9}$

In this paper, we use the political support function approach of Hillman (1989) within a twosector, two-factor (capital and labor) Heckscher-Ohlin framework. ${ }^{10}$ The government's objective function, also called the political-support function, is a weighted sum of the welfare of workers and capitalists. ${ }^{11}$ Maximization of this objective function yields the equilibrium tariff. In this model, the effect of an increase in the leftist orientation of the government is studied by increasing the weight on labor welfare relative to capital welfare in the government's maximand. This increase in the labor-welfare weight results in policies that are more pro-labor and that make the domestic terms of trade move in favor of the labor-intensive sector. In a capital-abundant country, the laborintensive good is the importable good and therefore, an increase in the leftist orientation of the government will result in a rise in import protection. In a labor-abundant country, however, the capital-intensive good is the importable and the labor-intensive good is the exportable. Therefore, an increase in leftist orientation in such a country that calls for a change in the domestic price ratio in favor of the labor-intensive exportable good will result in a decline in import protection. It is exactly this prediction about cross-country variation in trade policy that we are able to investigate empirically using cross-sectional data on government ideology (left, center, or right), capital-abundance and diverse measures of trade restrictions and openness.

It is important to note here that in this kind of a Heckscher-Ohlin framework, a left-wing (right-wing) government may want to make the import tariff negative in a labor-abundant (capital-

\footnotetext{
9 See for instance Magee, Brock and Young (1989) or Persson and Tabellini (2000).

10 There are other approaches to modeling endogenous trade policy. See, for instance, Feenstra and Bhagwati (1982), Findlay and Wellisz (1982) and Rodrik (1986) for the tariff-formation function approach, Grossman and Helpman (1994) for the political-contributions approach, Mitra (1999) for lobby formation using the politicalcontributions approach, Magee, Brock and Young (1989) for the campaign-contributions approach and Mayer (1984) for the median-voter approach. The classification terminology is borrowed from Rodrik (1995) to which the interested reader is referred for an excellent and comprehensive survey of the theoretical and empirical literature on the political economy of trade policy. For an elegant analysis of the different approaches within a unified framework, see Helpman (1997). For an in-depth survey exclusively of the empirical literature in the political economy of trade policy, see Gawande and Krishna (2001).

11 Grossman and Helpman (1994) use their political-contributions approach (based on the theory of menu auctions) to provide micro-foundations to the political-support function approach. In that sense, we are using a reduced form approach. An increase in the weight on labor welfare in our framework can thus be, for instance, interpreted as a switch in power from a right-wing government receiving contributions from the capital lobby to a left-wing government that has the labor lobby contributing to it.
} 
abundant) country if free-trade is considered the neutral situation (arising from equal weights on labor and capital). However, in the real world there are possibly other components of the tariff (arising from other factors or considerations) which are, in combination, always positive enough to make the overall tariff levels, that we observe, positive in countries of all degrees of capital abundance or scarcity, and with governments of all ideologies. Holding these other effects constant with respect to ideology, the overall import tariff can rise or fall with left-wing ideology to the extent that the positive or negative component that we focus on becomes more positive or more negative.

In carrying out our empirical analysis, we first represent political ideology using categorical variables (treating ideology as ordinal), and then test if the political ideology variable can be given a cardinal interpretation. Subsequently, we define our ideology variable as increasing in the left orientation of the party in power, so that the variable takes the value one for a right-wing government, two for a centrist government and three for a government that is classified as leftwing. In looking at the effects of ideology on protection, we allow these effects to change direction and magnitude as the relative factor proportions change when we move across countries. We perform our empirical investigation using three separate measures of relative factor endowments (capital per worker), constructed using different methods and under different assumptions. Across all measures of trade restrictiveness and using different measures of the capital-labor ratio, we find strong evidence in favor of the above-mentioned prediction of the impact of ideology on protection. An increase in the left-wing ideology, holding constant the economy's overall relative endowments, does in fact, raise trade barriers in capital-abundant economies and lower them in capital-scarce economies. ${ }^{12}$ Further, this result is extremely robust to the use of controls, to the treatment of the relative capital-labor endowments as endogenous to trade policy, to the correction of measurement errors in the ideology measure and to controlling for differences in the endowments of other factors of production.

\footnotetext{
12 In addition to using ideology as a variable, an interaction term between ideology and the capital-labor ratio is used to endogenously determine from the data the threshold capital-labor ratio where the trade restrictivenessideology relationship changes sign or direction.
} 
It is important to note here that our results are consistent with the results of econometric studies (using micro-level survey data) on individual level trade policy preferences such as Balistreri (1997), Beaulieu (2001), and Scheve and Slaughter (2001). These authors find that for both Canada and the US in recent years, factor type has been the dominant determinant of support for or opposition to trade barriers. Individuals owning proportionally more of the scarce factors are in favor of trade barriers, while those owning proportionally more of the abundant factors do not like trade restrictions.

The main theoretical proposition presented and investigated in our paper is driven by the Stolper-Samuelson effect and therefore, our empirical results can be interpreted only in the context of this effect. Besides the above individual-level, revealed preference evidence for the StolperSamuelson theorem, there are papers that have found support for it using data on Political Action Committee (PAC) contributions and congressional voting patterns. These studies specifically find support for the two-factor, capital-labor version of the Stolper-Samuelson effect, and thus, are specially relevant for our empirical investigation. Beaulieu (2000) finds some evidence of congressional voting patterns on trade policy in the US being affected by the factor-endowment composition of constituencies. One of the interesting empirical regularities unravelled by his study is a negative relationship between the likelihood that a candidate votes in favor of the CUSTA, GATT or NAFTA and the size of contributions from labor PACs. He also finds a positive effect of contributions from capital (corporate) PACs on the likelihood of a favorable vote for CUSTA. In the case of the GATT and the NAFTA, however, he finds no effect of capital contributions. Kahane (1996) finds that after controlling for state characteristics, the likelihood of voting against the NAFTA in both the House and the Senate was increasing in contributions by labor PACs. Steagall and Jennings (1996) find that the likelihood of a favorable House vote for the NAFTA was again decreasing in labor contributions, but also increasing in capital (corporate) contributions. However, contributions are endogenous to political and other leanings of the candidate. Baldwin and Magee (1998), after taking into account this endogeneity, find strong evidence that the likelihood of a 
favorable vote for the NAFTA or the GATT cast in the House was decreasing in labor contributions but increasing in business contributions. Beaulieu and Magee (2000) determine industry affiliation of these capital and labor PACs. They find that both the probability of a capital PAC contributing money to a candidate and the size of its contribution to a candidate were higher if he/she was a supporter of NAFTA, while the reverse was true for a labor PAC. Industry affiliation of these PACs did not seem to matter in their contributions decisions in this NAFTA context. ${ }^{13}$

The contribution of our paper is two-fold. Firstly, our results uncover a robust empirical regularity in the relationship between trade protection and political ideology, thereby adding to the empirical literature on political economy of trade policy. Our findings suggest that a left-wing government that is generally more interventionist and believes in state control of the economy may, under certain conditions, have a preference for free trade. Secondly, the paper adds to the empirical literature on cross-national variation in protection. ${ }^{14}$

In section 2, we present the theoretical framework and perform a comparative-static exercise to derive the implications of an increase in the extent of left-wing ideology (the government's weight on labor welfare) for trade policy determination. Section 3 describes the specification of the econometric model and explains the various inferences that the model allows. Section 4 briefly discusses the data and the choice of regressors. In section 5 , we discuss our empirical results and finally, in section 6 , we make some concluding remarks.

\footnotetext{
13 In contrast to the studies mentioned above, earlier studies (using older data) by Irwin (1994, 1996) and Magee (1978) find that industry of employment was the major determinant of individual level trade policy preferences in the British elections of the early twentieth century and in the testimonies of trade unions, management and industry associations before the House Ways and Means Committee on the Trade Reform Act of 1973 in the US respectively. However, Rogowski (1987) shows how coalitions formed in the US, Britain, and Germany in the nineteenth century are those predicted by the Heckscher-Ohlin model.

14 See Rodrik (1995) for a discussion of the importance of (and the need for) empirical work on cross-country variations in protection. To our knowledge, there are only two cross-country empirical studies on protection. Magee, Brock and Young (1989, ch. 16) find that average tariff rates tend to decrease as capital-labor ratios increase. Mansfield and Busch (1995) examine cross-national variation in average protection levels among 14 advanced industrial countries pooled over two years, 1983 and 1986. They find that non-tariff barriers are increasing in country size, unemployment rate and number of parliamentary constituencies, and are higher for countries that use proportional representation as their electoral system. Also, there are three well known cross-industry studies on protection in the US - Goldberg and Maggi (1999), Gawande and Bandyopadhyay (2000) and Trefler (1993) all of which focus on the predictions of lobbying/political contributions models about cross-industry variation in protection.
} 


\section{Theoretical Framework}

Let us consider a two-factor, two-sector, small-open, Heckscher-Ohlin economy. We choose units such that the world-price ratio of the two goods is one. Let $t$ be the ad valorem import tariff. Therefore, the tariff-inclusive domestic relative price of the importable good is $\tau=1+t$. Both goods require both capital and labor in their production which is carried out under constant returns to scale. On the demand side, individual preferences are taken to be identical and homothetic. An individual h's indirect utility function can, therefore, be written as $\Omega^{h}=V(\tau) I^{h}(\tau)$ where $I^{h}$ is her income.

For simplicity, we assume that there are two kinds of factor owners, workers (who only own labor) and capitalists (who only own capital). Let us denote the set of all capitalists by $\mathcal{K}$ and the set of all workers by $\mathcal{L}$. Furthermore, we let $K$ stand for the aggregate capital stock of the economy, while $L$ is the total labor endowment of the economy. The total incomes of all capitalists and of all workers are given respectively by

$$
\begin{gathered}
I^{\mathcal{K}}(\tau)=r(\tau) K+(\tau-1) \phi^{\mathcal{K}}(\tau) M(\tau) \\
I^{\mathcal{L}}(\tau)=w(\tau) L+(\tau-1)\left(1-\phi^{\mathcal{K}}(\tau)\right) M(\tau)
\end{gathered}
$$

where $\phi^{\mathcal{K}}$ is the share of capitalists in the total tariff revenue (equal to their share in national factor income by assumption) and $M(\tau)$ denotes total imports. $w(\tau)$ and $r(\tau)$ are the wage rate earned by labor and rental on capital respectively, both being solely the functions of the domestic price of the importable.

The government chooses the level of the import tariff to maximize its objective function which is a weighted sum of the aggregate welfare of workers and capitalists. Thus, the government's objective function is given by

$$
\Omega^{\mathcal{G}}(\tau)=\alpha \sum_{h \in \mathcal{L}} \Omega^{h}(\tau)+(1-\alpha) \sum_{h \in \mathcal{K}} \Omega^{h}(\tau)
$$


Due to the homotheticity of preferences, the above objective function can be written as

$$
\Omega^{\mathcal{G}}(\tau)=V(\tau) I^{\mathcal{G}}(\tau)
$$

where $I^{\mathcal{G}}$ is the weighted aggregate income given by

$$
I^{\mathcal{G}}=\left[\alpha \sum_{h \in \mathcal{L}} I^{h}(\tau)+(1-\alpha) \sum_{h \in \mathcal{K}} I^{h}(\tau)\right]=L[\alpha w(\tau)+(1-\alpha) r(\tau) k][1+\delta(\tau ; k)]
$$

where $k$ is the ratio of capital to labor endowment of a country and $\delta($.$) is the ratio of total$ tariff revenue to national factor income. Let $I_{u}^{\mathcal{G}}$ be the above weighted income for a country of unit size, i.e., it is the value of $I^{\mathcal{G}}$ at $L=1$. The government maximizes $L V(\tau) I_{u}^{\mathcal{G}}(\tau)$ which is the same as maximizing $V(\tau) I_{u}^{\mathcal{G}}(\tau)$. In other words, the endogenous tariff will depend on $\alpha$ and $k$ and for given values of these parameters, not on the country size $L$. The government's problem is equivalent to maximizing $v(\tau)+i(\tau ; \alpha, k)$ where $v(\tau)=\ln V(\tau)$ and $i=\ln I_{u}^{\mathcal{G}}$. It is assumed that this objective function is strictly concave with respect to the domestic price (second-order condition for a unique interior solution). Expanding the expression for $i$, we have $i=\ln [\alpha w(\tau)+(1-\alpha) r(\tau) k]+\ln [1+\delta(\tau ; k)]$. The first order condition of our maximization problem gives us

$$
v^{\prime}(\tau)+\partial i / \partial \tau=0
$$

Let $t^{*}=\tau^{*}-1$ be the equilibrium tariff coming out of the government's maximization problem described above. We now want to see how this tariff varies with the government's weight, $\alpha$, on labor welfare. Differentiating our first order condition to perform comparative statics we obtain

$$
\frac{\partial t^{*}}{\partial \alpha}=\frac{\left[r^{\prime}(\tau) w(\tau)-r(\tau) w^{\prime}(\tau)\right] k}{[\alpha w(\tau)+(1-\alpha) r(\tau) k]^{2}\left[v^{\prime \prime}(\tau)+\partial^{2} i / \partial \tau^{2}\right]}
$$

Since an increase in the domestic price of the importable increases the reward to the scarce factor and reduces that for the abundant factor, we have $r^{\prime}(\tau)<0$ and $w^{\prime}(\tau)>0$ for a capital-abundant country, while $r^{\prime}(\tau)>0$ and $w^{\prime}(\tau)<0$ for a labor-abundant country. The denominator in $(7)$ is always negative due to the restriction of concavity imposed on the objective function. Thus, the above derivative of $t^{*}$ with respect to $\alpha$ is positive when the economy is capital abundant, so 
that an increase in the left orientation leads to an increase in the equilibrium tariff. For a labor abundant country, this derivative has a negative sign.

This result is very intuitive. An increase in left orientation always results in an increase in redistribution through policies that would benefit labor. In a capital abundant country, the importable is the labor intensive good and an increase in redistribution from capital to labor would increase the bias of policies in favor of the importable sector. In a labor abundant economy, the importable sector is the capital intensive sector and hence more redistribution towards labor requires policies that are more biased against the importable sector. This leads us to the following proposition whose empirical validity we test in this paper.

Proposition: Holding other things constant, an increase in the left orientation (prolabor bias) of the government leads to more restrictive or less open trade policies in capital abundant countries, while it leads to less restrictive or more open trade policies in capital scarce economies.

While the predictions are not as precise once we allow for more than two factors, we will attempt to argue that the predictions stated in the above proposition are not as specific to the two-factor framework as they appear. First, let us assume that there are three factors - physical capital $(K)$, human capital or skills $(H)$ and raw, unskilled labor $(L)$. National income for a country with unit size $(L=1)$ will depend on the physical capital to labor ratio $(k)$ and the human capital to labor ratio $(h)$ and will equal $r k+w_{H} h+w$ where $w_{H}$ denotes the return on human capital. ${ }^{15}$ Thus, in order to be rich (poor), countries have to be relatively abundant (scarce) in $K$ and $H$ combined or relatively scarce (abundant) in $L .^{16}$ Prolabor redistribution

\footnotetext{
15 Note that an increase in $L$, holding constant $h$ and $k$, means an increase in both the other factors in the same proportion.

16 Endowments of physical and human capital should be correlated (both at the country and individual levels), as it is the marginal rate of time preference that determines the steady state levels of both in the absence of credit market imperfections, while in the presence of such imperfections, the ownership of physical assets directly affects the ability to acquire skills.
} 
policies in rich (poor) countries, thus, lead to higher (lower) trade barriers. ${ }^{17}$

\section{$3 \quad$ Econometric Methodology}

As the comparative static result of the previous section shows, in countries with high $(K / L)$ ratios, left-wing ideology of the government and trade restrictiveness should be positively related, but when $(K / L)$ is low there is an inverse relationship between these two variables. A priori, we do not know at what level of $(K / L)$, this relationship changes sign. The following specification takes care of this problem by allowing the data to tell us the exact location of this turning point:

$$
T R_{i}=\alpha_{0}+\alpha_{1} \text { Ideology }_{i}+\alpha_{2} \text { Ideology }_{i} \times(K / L)_{i}+\alpha_{3}(K / L)_{i}+\mathbf{X}_{i} \beta+\epsilon_{i}
$$

where $T R_{i}$ is the extent of trade restrictions in country $i$, Ideology $_{i}$ is a measure of the extent of the government's left-wing ideology, $(K / L)_{i}$ the capital-labor ratio and $\mathbf{X}_{i}$ is a row vector of control variables ${ }^{18},{ }^{19}$. The inclusion of $(K / L)$ as a separate variable (in addition to Ideology and Ideology $\times(K / L))$ allows $\frac{\partial T R_{i}}{\partial(K / L)_{i}}$ and the variable component of $\frac{\partial T R_{i}}{\partial(\text { Ideology })_{i}}$ to differ in sign. Otherwise, they are restricted to having the same sign.

Taking the partial derivative of $T R_{i}$ with respect to Ideology $y_{i}$, we have

$$
\frac{\partial T R_{i}}{\partial(\text { Ideology })_{i}}=\alpha_{1}+\alpha_{2}(K / L)_{i}
$$

\footnotetext{
17 If we go beyond three factors, our basic result qualitatively will still hold though it might be weakened a bit. The higher dimensional version of the Stolper-Samuelson theorem implies that if a factor is "scarce enough" ("abundant enough"), it will be helped (harmed) by trade barriers (See Leamer and Levinsohn, 1995). Consider a continuum of types of skills (high level or high paying to low level or low paying) and types of physical assets (high tech and high return like computers to low tech and low return like hammers, screw-drivers, etc). Rich countries will be abundant in the higher end factors, while poor countries in the lower end factors. A redistribution from the rich to the poor through trade policy will, thus, take the form of high (low) trade barriers in the very rich (poor) countries.

18 We could not find any non-monotonicities with respect to $K / L$ by including an additional term $(K / L)^{2}$. We did not detect any non-linearities (at $15 \%$ and even higher levels of significance) in any of our variables $(K / L$, ideology, their cross product and other control variables) when we performed the Ramsey Reset test for all our regressions, both with and without controls.

${ }^{19}$ In our estimation, we use the capital-labor ratios in natural logs (and not in levels). For the TARIFF regression, we have only one outlier with logs but 19 outliers with levels. For the IMPORT DUTY regression, the numbers are zero and 22 respectively, while for the $(X+M) / G D P$ regression the difference is even more stark, 3 outliers with logs and 43 with levels. The number of outliers are somewhat comparable in the case of the QUOTA, 24 with logs and 32 with levels. Moreover, in the case of logs, the results are robust to the deletion of outliers. Thus, we present results with $K / L$ in logs throughout this paper.
} 
The prediction of the comparative static exercise of the previous section is that $\alpha_{1}<0$ and $\alpha_{2}>0$ such that $\alpha_{1}+\alpha_{2}(K / L)_{i} \gtrless 0$ as $(K / L)_{i} \gtrless(K / L)^{*}$ where $(K / L)^{*}=-\alpha_{1} / \alpha_{2}$ is the turning point capital-labor ratio determined endogenously from the data, given our estimating equation. ${ }^{20}$ Another requirement for the prediction to hold is that $(K / L)^{*}$ should lie within the range of values of $(K / L)$ in the dataset, i.e., $(K / L)^{M I N}<(K / L)^{*}<(K / L)^{M A X}$.

We first run the basic (without controls) ordinal and cardinal versions (explained in detail in subsection 5.1) of the above estimating equation. We then add controls such as democracy and special dummies for East Asia, for Oil countries and for Sub-Saharan African countries to see whether our results are robust to their inclusion. ${ }^{21}$ Hausman tests ${ }^{22}$ suggested the endogeneity of the capital-labor ratio with respect to trade protection. We therefore, perform two-stage least squares regressions to control for such endogeneity. We also take advantage of the fact that two of our measures of protection have a time-series dimension to create a panel data set and validate our results using a fixed-effects model with time-specific and comprehensive region-specific effects. Furthermore, we investigate whether this model works better in democracies than in dictatorships and where the magnitude of this predicted relationship is stronger.

We also perform a number of robustness checks. We try to experiment with some suggested adjustments to the political ideology variable and we also try to control for region-specific measurement errors in this variable (arising from region-specific elements in the definition of left vs. center vs. right). In addition, we provide some indirect checks that test the quality of our ideology variable. Finally, we try to control for differences in the land endowment across nations

\footnotetext{
20 We will first give ideology a categorical interpretation and subsequently check if it may be given a cardinal interpretation as well. If ideology has an exclusively categorical (dummy variable) interpretation then the derivatives shown here are not very meaningful. However, we can still find critical capital-labor ratios where the relationships switch sign.

21 We have also tried using in addition to these controls a dummy for Latin America. The results remain completely unaffected.

${ }^{22}$ In a linear model, an easy way of implementing the Hausman test for exogeneity is to first run reduced form regressions of each of the variables (in our case, $K / L$ and Ideology $* K / L$ ) that are suspected to be endogenous on all the exogenous variables from our main regression and other exogenous variables which theory suggests might affect any of these endogenous variables. The second step involves computing the residuals from each of these auxilliary regressions and inserting them as additional right-hand side variables in our main estimating regression. If these residuals are jointly significant, our plain OLS estimation of the model produces inconsistent estimates warranting a 2SLS estimation.
} 
and attempt to see whether land-owners generally form coalitions with capitalists or workers.

\section{Data Sources and Some Basic Statistics}

Our dependent variable is trade protection and our independent variables of interest are a measure of ideological orientation (left, center and right wing), the capital-labor ratio, and indicators for democracy and political rights. For the regional effects, we will be using region-specific dummies. Unless otherwise mentioned, the cross-sectional analysis averages all variables for the decade of the 1980s and the panel analysis covers the time period 1980-1989.

To test for the robustness of our results, we use a variety of trade policy measures: total import duties collected as a percentage of total imports (IMPORT DUTY), an average tariff rate calculated by weighing each import category by the fraction of world trade in that category $(\mathrm{TARIFF})^{23}$, a coverage ratio for non-tariff barriers to trade (QUOTA) and an indirect measure of trade restrictions - the magnitude of trade flows relative to GDP, defined as $(X+M) / G D P$. For tariff and quota we have only one observation per country, while for import duty and $(X+$ $M) / G D P$ we use decade averages in the cross-country analysis. For the panel analysis, only IMPORT DUTY and $(X+M) / G D P$ are used since these are the only measures for which data are available over time.

The data on political orientation are obtained from the Database of Political Institutions (DPI) (Beck et al, 2001). The authors have created a large cross-country database of political institutions that covers 177 countries over 21 years, 1971-1995. The database, among many other things, also lists the political orientation of the chief executive (that of the chief executive's party or when considered appropriate that of the chief executive himself/herself) and of the majority party in the legislature as 'Left', 'Center' or 'Right'. We use the ideological orientation of the chief executive for political systems classified as presidential in the database, that of the largest government party for systems classified as parliamentary, and the average of these two orientations

\footnotetext{
23 The variable is referred to as tariffs, although it includes all import charges, such as duties and customs fees.
} 
for systems classified as assembly-elected president. We also verified the robustness of our results by using the ideological orientation of the chief executive for political systems that are classified as assembly-elected president instead of using an average measure. The results are robust to such a variation. Similar data have been used by Hibbs (1977) and Alt (1985) who examined the partisan effects of left vs. right-wing governments on unemployment and inflation rates. They find that left-wing governments are more labor-oriented, draw their support from the working-class and attach far greater importance to issues such as unemployment and equalization of the income distribution. In contrast, right-wing parties are business-oriented and attach low priority to labor related issues such as unemployment while assigning high priority to price stability. Alesina and Roubini (1992) use data on ideological orientation for more direct tests of rational partisan theory (Alesina, 1987) and its implications for political business cycles.

The data on capital-labor ratios are obtained from Easterly and Levine who use aggregate investment and depreciation data to construct capital per worker series for 138 countries. To check for, and ensure the robustness of our results we also use the Easterly-Levine capital per worker data that uses disaggregated sectoral investment data along with information on disaggregated sector-level depreciation to arrive at more accurate measures. However, the country coverage is much smaller than the aggregate Easterly-Levine capital-labor series. ${ }^{24}$

For a measure of democracy, we use the Freedom House (Gastil) measure of democracy that provides a subjective classification of countries on a scale of 1 to 7 on political rights, with higher ratings signifying less political freedom. Finally, as instruments, the additional variables used are the natural logarithm of the savings rate and the population growth rate obtained from the World Development Indicators. Note that the population growth rate and the savings rate

\footnotetext{
24 We also tried the Nehru-Dhareshwar data on capital in conjunction with the data on labor (defined as population between ages 15 and 64), to calculate an alternative measure of capital-labor ratio. The data on capital stock at 1987 domestic prices are converted into 1987 constant dollars using the 1987 exchange rate. However, this results in a number of outliers (both in terms of unrealistically high capital-labor ratios for countries such as Argentina and in terms of multivariate outlier tests) owing to appreciated exchange rates. The results (with and without the inclusion of these outliers) here bear out our predictions as well, and are available from the authors upon request.
} 
are parameters in the Solow growth model in which the steady state per-capita capital stock is determined endogenously.

For some additional regressions, we also use data on government and opposition fractionalization, also obtained from the DPI. The data on these variables are only available for countries with parliaments or their equivalent.

The summary statistics for the main variables and the correlation matrix for our protection measures are presented in tables 0.1 and 0.2 respectively.

\section{Results}

\subsection{OLS Regressions (With and Without Controls)}

We first show that our basic theoretical prediction is supported when we give ideology an exclusively ordinal or categorical (dummy variable) interpretation. Under this interpretation, our estimating equation is

$$
T R_{i}=\alpha_{0}+\alpha_{1} *(K / L)_{i}+\beta_{0} \text { left }_{i}+\beta_{1} \text { left }_{i} *(K / L)_{i}+\gamma_{0} * \text { center }_{i}+\gamma_{1} * \operatorname{center}_{i} *(K / L)_{i}+\epsilon_{i}
$$

where left $_{i}=1$ (0 otherwise) if the $i^{\text {th }}$ country has a left-wing government and center $_{i}=1(0$ otherwise) if the $i^{\text {th }}$ country has a centrist government. Both $\beta_{0}$ and $\gamma_{0}$ are predicted to be negative whereas $\beta_{1}$ and $\gamma_{1}$ are predicted to be positive. Also theory predicts that the $\beta^{\prime}$ s are greater in magnitude than the respective $\gamma$ 's. Next, we perform tests to check if, in fact, the ideology measure can be treated as cardinal, where it takes the value 1 if the government is right-wing, 2 if it is centrist, and 3 if it is left-wing. Under this interpretation, equation (8) is our estimating equation. We check if the cardinal specification (a special case of the ordinal specification) is valid by testing the following joint hypothesis

$$
\beta_{0}=2 \gamma_{0} \text { and } \beta_{1}=2 \gamma_{1}
$$

If we cannot reject this joint hypothesis, then there are efficiency gains from treating ideology as a cardinal measure, with equal distances between right and center and between center and left ${ }^{25}$.

\footnotetext{
${ }^{25}$ In the results that follow, all standard errors are White-corrected.
} 
In table 1, we present our first set of cross-section results. In the first four regressions, we use a single dummy variable that takes the value 1 for left wing governments (and zero otherwise) to represent ideology. For the last four columns, we add another dummy for "center" that additionally distinguishes countries with centrist governments from the rest. Classification of political ideology was done as follows: The time period of our study is the decade of the 1980s. Any country that had a left-wing (centrist/right-wing) government in office for at least 6 years was coded as 'left'('centrist'/'right'). There are three countries in our sample - Bolivia, New Zealand and Norway, that had a left-wing and a right-wing government for exactly 5 years each during the 1980s, and one country - Ecuador - that had a left-wing and a right-wing government for exactly 4 years each, and a centrist-government for a year. ${ }^{26}$ These countries were classified as centrists. ${ }^{27}$ There was no other country whose political ideology split up into all three types (left, right and center) for the decade of the 80's. As the first four columns of table 1 show, left wing governments are more protectionist in capital-abundant countries but less protectionist in laborabundant countries. $^{28}$ The critical capital-labor ratio varies from 9.6 for $(X+M) / G D P$ to 10.6 for QUOTA, not far from the mean and median capital-labor ratios. While the result for import duty is somewhat weak in terms of the significance of the individual coefficients, the model as a whole is significant. The $R^{2}$ 's in the first four regressions range from 0.15 to 0.35 .

In the next four columns, we further partition the non-left countries into centrist and rightwing by using two dummies - one for 'left' and one for 'center'. We interact both these two dummies with the capital-labor ratio. Our results do not change qualitatively from the first four columns. Generally, we find that left wing governments are more protectionist than governments classified as right-wing in capital-abundant countries but less protectionist in labor-abundant countries. This

\footnotetext{
26 For Ecuador, we have data for only 9 out of 10 years in the decade of the 80 s.

27 To check for the robustness of this classification, we tried the following permutations: a) classifying these countries as left-wing; b) classifying them as right-wing; and c) dropping them from the sample. Our results are robust to all such variations.

28 We have similarly performed regressions where we look at right versus non-right nations, where we find that right wing governments are more protectionist than left wing ones in labor-abundant countries. The relationship is reversed for capital-abundant countries. The results are as strong as the ones reported in the paper for left versus non-left, and are available from the authors upon request.
} 
result also holds for centrist versus right-wing governments with QUOTA and $(X+M) / G D P$ as dependent variables. There are two critical capital-labor ratios (one for right vs. center and another for right vs. left) per regression because of which we do not show them in the table. These critical values are all very close to 10 , again very close to the mean and median values of $(K / L)$. As before, the model as a whole is significant and here the $R^{2}$ 's ranges from 0.19 to 0.35 .

Importantly, we see here that we cannot reject the hypothesis that ideology can be treated as cardinal (i.e., the joint hypothesis that $\beta_{0}=2 \gamma_{0}$ and $\beta_{1}=2 \gamma_{1}$ ) for all measures except $(X+M) / G D P$. In other words, we can replace these ideology dummy variables with a cardinal measure of ideology and obtain more efficient parameter estimates. Therefore, for most of the rest of the paper we will treat ideology as cardinal. As mentioned before, we recoded the ideological orientation of the government of each country for each year as follows - 3 for left, 2 for center, and 1 for right. For our cross-sectional regressions, we take the average of this variable for the 80's. Therefore, our ideology variable in the regressions is best interpreted as the extent to which the policy and decision-making authority can be considered left-wing with higher numbers signifying a more leftist orientation. Apart from being a cardinal variable that will yield more efficient estimates (because the cardinality hypothesis cannot be rejected), this variable through decadewide averaging, in our cross-sectional regressions, also captures the variation in the proportion of years a country had regimes that differ in their ideological orientations (which our ordinal variables do not).

Tables 2 and 3 present the regression results (with and without controls) for our main estimating equation (equation (8) in section 3 of this paper) with the cardinal measure of ideology. Table 2 corresponds to the Easterly-Levine aggregate capital-labor ratio (our main measure due to more extensive country coverage), and table 3 to the Easterly-Levine disaggregated capital-labor ratio. The sample size which ranges from 35 to 89 , depends on the country coverage of the data on the different variables used.

In table 2, all our regression models as a whole are significant at the $5 \%$ level. In addition, 
as predicted, we obtain a negative sign for ideology and a positive sign for the interaction term for tariffs, quotas and import duty where these coefficients are individually as well as jointly significant. For $(X+M) / G D P$ (a measure of openness) as predicted the signs are reversed and significant. The table also reports the critical capital-labor ratio at which the relationship between trade protection and left-wing ideology switches from negative to positive. The critical capitallabor ratio at which the relationship between trade protection and left-wing ideology switches from negative to positive, ranges from 9 (for $(X+M) / G D P$ without controls) to 10.5 (for quota without controls). These values are very close to the median and mean capital-labor ratios in the sample. ${ }^{29}$ The $R^{2}$ ranges from 0.2 (in the case of quota without controls) to 0.38 (in the case of tariffs with controls). The results are the strongest and most robust for tariffs and quotas, which are the most direct measures of trade restrictions.

Even though our model can explain less than $40 \%$ of the cross-country variation in protection, we still are able to analyze the magnitudes of some of the partial derivatives of protection with respect to ideology. For example, let us consider two capital-scarce countries, Bangladesh $(K / L=$ 7.34) and Senegal $(K / L=7.17)$. While Bangladesh had a right-wing government (Ideology $=1)$, Senegal had a left-wing government $($ Ideology $=3)$ in the 80 's. At the average of the two $K / L$ ratios $(K / L=7.255)$, from our tariff regression without controls, we have $\partial$ Tarif $f / \partial I$ deology $=-0.1$. Bangladesh had a tariff of 0.41 and Senegal had a tariff of 0.19 , a difference of 0.22 , resulting in a slope of the tariff with respect to ideology of about -0.11 which is very close to the estimated slope from our regression. Let us now compare two capital abundant countries, Canada $(K / L=11.12)$ and USA $(K / L=11.2)$. While the US had Ideology $=1.2$ (average for the 80's), Canada had Ideology $=1.8$. At the average of the two $K / L$ ratios $(K / L=11.16)$, from our tariff regression

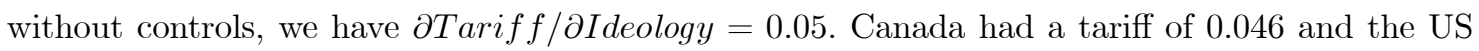
had a tariff of 0.02 , a difference of 0.026 , resulting in a slope of the tariff with respect to ideology

\footnotetext{
29 Of course, it must be noted that the critical capital-labor ratio is itself an estimate and has a standard error. However, for most of our regressions, the 2 standard error confidence interval around this estimate includes the median and mean capital-labor ratios. Thus the capital-labor ratio according to which countries are classified as labor and capital abundant emerges endogenously from our analysis.
} 
of 0.043 which is very close to the estimated slope from our regression. Brazil, Korea, Algeria, Costa Rica, Jamaica and Guyana that have capital-labor ratios close to the critical values also have roughly similar tariff rates even though the political ideologies of their governments are quite different.

In table 3, which uses the disaggregated capital-labor ratio, our estimates (ideology, $K / L$, and the interaction term) are significant, except for the import duty regressions where ideology and the interaction term are insignificant ${ }^{30}$ (even in which case they do have the correct signs and the model as a whole is significant at the $5 \%$ level and accounts for upto $45 \%$ of the cross-country variation without controls and upto $55 \%$ when we add controls). The $R^{2}$ ranges from 0.28 for the $(X+M) / G D P$ without controls to 0.55 for the import duty regression with controls.

In table 4, using the tariff regression without controls presented in table 2, we categorize the countries in our sample into those that exhibit a negative relationship between protection and leftwing ideology (those with a low capital-labor ratio) and those that exhibit a positive relationship (those with a high capital-labor ratio). The critical (turning point) capital-labor ratio in this case is roughly 9.9 which is slightly lower than the capital-labor ratio for Ecuador. Adding controls increases the number of countries that exhibit a negative relation between left-wing ideology and trade protection and diminishes the number of countries that exhibit a positive relation.

A partial derivative of trade restrictions with respect to the capital-labor ratio (using equation (8)) in the regressions yields

$$
\frac{\partial T R_{i}}{\partial(K / L)_{i}}=\alpha_{3}+\alpha_{2}\left(\text { Ideology }_{i}\right)
$$

Our regression results show that $\alpha_{3}<0$ and $\alpha_{2}>0$ and that their estimates are statistically significant. Substituting the values of Ideology $i$ into the expression for the above partial derivative, we find a negative sign for all countries in our sample. These results are in line with the findings of Magee et al. (1989). Tariffs are a dependable and important source of revenues in developing

\footnotetext{
30 Notice that the country coverage for the disaggregate capital-labor ratio is nearly half that of the aggregate capital-labor ratio.
} 
countries (countries with a low capital labor ratio). Moreover, developing countries have used infant-industry reasoning to justify protecting domestic industries.

We now look at the coefficients of our control variables in tables 2 and 3 . Our controls are an inverse index of democracy (the Gastil index of political rights) ${ }^{31}$, and regional effects using regional dummies. The inclusion of democracy is motivated by several factors. First, if we believe the evidence that openness stimulates economic growth, dictatorships which are more concerned with the size of the pie rather than its distribution, are more likely to be open. Second, since unemployment is a major issue in most elections, democracies are also more likely to provide import protection to inefficient domestic firms and to public sector firms in particular, that may not survive foreign competition. Furthermore, Fernandez and Rodrik (1991) show that in the presence of individual-specific uncertainty regarding the costs of moving to the export sector, trade reforms that are beneficial to the majority ex-post may require a dictator to implement them in the first place. ${ }^{32}$ However, as tables 2 and 3 show, we fail to find any evidence that democracies are more protectionist. The relationship between democracy and the partisan model is addressed in greater detail in later sections. Finally, in terms of regional effects all we find is that quota coverage is lower for East Asian countries and that quotas and import duties are higher for sub-Saharan African countries.

\subsection{Two Stage Least Squares}

In a dynamic context (for example in a multi-sector Solow model), the capital-labor ratio may be endogenous with respect to trade policy. Protection, by affecting the production structure, can affect accumulation and the steady state level of the capital stock. Because of the possible endogeneity of the capital-labor ratio and the interaction term, we performed a two-stage least

\footnotetext{
31 Note that this index increases with the extent of dictatorship and decreases with the degree of democracy

32 Also, Rodrik (1997) has argued that rising labor demand elasticities, brought about by more open trade, may hurt workers (the majority of the population) by shifting the wage or employment incidence of non-wage labor costs towards labor and away from employers, by triggering more volatile responses of wages and employment to labor demand shocks and by bargaining power over rent distribution in firms away from labor and towards capital. This may generate some demand for protection, to which democracies may be more responsive.
} 
square estimation where we instrument the suspected endogenous terms by the log of the population growth rate and the log of the savings rate. In the case of the cardinal regressions we have two endogenous terms $(K / L)$ and $\operatorname{Ideology} *(K / L)$ and so these two instruments are enough to ensure that the estimating equation is identified. For the ordinal regressions, there are three endogenous terms and so we use both the first order and second order terms in the saving rate and the population growth rate (levels, squares, and the cross-product) as instruments to ensure the identification of the equation. ${ }^{33}$

As table 5 shows across all measures of protection, the prediction of the partisan model is supported. The relevant terms are all significant and the critical capital-labor ratios are again very close to the mean and the median. These results are also robust to the inclusion of controls.

\subsection{Panel Regressions}

We also test our model using cross-sectional time series data available for two measures of protection - import duty and $(X+M) / G D P$. We use a fixed-effects model with time and comprehensive region-specific effects. ${ }^{34}$ In general, time specific shocks seem more reasonable because historically the world as a whole has exhibited a pattern, where either all countries have tended to become more protectionist (e.g., the inter-war years), or less protectionist (the mid 1990s following the Uruguay Round). Further, there has been a tendency for countries within a region to organize themselves into free trade areas or customs unions - an effect that should be captured by our comprehensive region-specific effects. Finally, due to the endogeneity of capital-labor ratio with respect to tariffs, we use instrumental variables - the log of the savings rate and log of the popula-

\footnotetext{
33 In fact with the levels, squares and the cross-product of the saving rate and the population growth rate, the estimating equation is overidentified. However, it allows us to check the quality of our instruments by performing the appropriate tests for the overidentifying restrictions. We are unable to reject those restrictions. Even for our cardinal regressions, we perform this test by including the second-order terms as instruments and we are unable to reject the overidentifying restrictions. Thus, our instruments are valid and of good quality. The 2SLS cardinal results with the extra second-order terms are very similar to the ones with only the levels as instruments.

${ }^{34}$ A fixed effects model with country-specific effects on the other hand, will not be able to identify the estimates for some of our variables that do not vary within groups over time - for instance, the regional dummies. Moreover, with 50-60 countries in each regression, such an approach uses up large degrees of freedom and results in high multicollinearity between the country-specific effects and some of the right-hand side variables, making the interpretation of the coefficients difficult.
} 
tion growth rate. Even though one would expect that the preferences of the government (and/or those of the interest groups influencing it) would take time to affect the level of protection, our predictions are borne out here as well in the case of the import duty measure. This is reassuring especially since import duty is the only direct measure of protection for which we have data over time. The following panel regression result with time-specific and very comprehensive regionspecific effects (with $(K / L)$ and ideology $*(K / L)$ instrumented by the log of the saving rate and the $\log$ of the population growth rate) has the expected signs for the relevant variables whose coefficients are significant at the $1 \%$ level:

$$
\begin{aligned}
\text { Imp Duty } & =\underset{(12.82)}{63.35^{* * *}} \text { ideology }+\underset{(1.26)}{6.31^{* * *}} \text { ideology }(K / L)-\underset{(3.79)}{19.84^{* * *}}(K / L)+\text { fixed effects } \\
R^{2} & =0.23, N=610
\end{aligned}
$$

The asterisks represent significance levels as in the tables with the standard errors in parentheses. The critical $(K / L)$ ratio is 10 , again very close to the mean and the median value. A left versus non-left regression based on the ordinal measure also gives us similar results:

$$
\begin{aligned}
& \text { Imp Duty }=-\underset{(19.63)}{105.26^{* * *} l e f t}+\underset{(1.93)}{10.42^{* * *}} \operatorname{left}(K / L)-\underset{(1.94)}{11.08^{* * *}}(K / L)+\text { fixed effects } \\
& R^{2}=0.27, N=610
\end{aligned}
$$

Note that in a regression with additional "center" intercept and interaction slope dummy we are unable to reject the hypothesis that a centrist government is no different from a right-wing one at any given level of $(K / L)$. The coefficient estimates of the "left" dummy and its interaction with $(K / L)$ are similar to the above estimates in sign, magnitude, and significance. Again, as in the case of our cross-sectional regressions, we cannot reject the hypothesis that ideology has a cardinal interpretation.

Our other measure that has a time dimension is $(X+M) / G D P$ which is an indirect, inverse measure of protection. This measure produces the correct signs but the coefficient estimates are not statistically significant. 


\subsection{Dictatorship vs. Democracy}

Next we investigate in this paper whether partisan concerns are more important in democracies or in dictatorships. Democratic governments, to ensure their re-election, may adopt policies that benefit their electoral base (groups that provide large blocks of votes and/or provide campaign contributions) - capitalists (business groups) for right-wing parties and labor (trade unions) for left-wing parties. Dictatorships on the other hand face few such incentives. On the other hand, dictatorships are less constrained in their redistributive attempts. Thus, we have an important empirical question at hand, namely whether the partisan model performs better for democracies than for dictatorships or vice-versa. We investigate two possible considerations: (a) whether the partisan model fits the data better for democracies than for dictatorships, and (b) whether the predicted relationship between trade policy and ideology is stronger (larger in magnitude) for democracies than for dictatorships.

We investigate (a) by generating residuals from our main regressions and then regressing the absolute values of these residuals on the democracy/dictatorship (political rights) variable. As we can see from the regression results below, for all our direct measures of trade policy (tariff, quota and import duty), we do find that these absolute residuals are higher for dictatorships suggesting that our model fits better for democracies: $\mid$ Tariff $R$ Residual $\mid \underset{(0.014)}{0.026^{* *}}+\underset{(0.003)}{0.006^{* * *}}$ (Dictatorship Measure), $\mid$ Quota Residual $\mid \underset{(0.028)}{0.115^{* * *}}+\underset{(0.007)}{0.015^{* * *}}$ (Dict. Measure), $\mid$ Imp Duty Residual $\mid=\underset{(0.71)}{3.05^{* *}+}$ $0.516^{* * *}($ Dict. Measure $)$. $(0.0 .228)$

Next, we generated predicted values of protection from our regressions without controls and found their correlation with the actual values separately for the dictatorship sample (Gastil measure above 4) and the democracy sample (the rest). The correlation coefficients shown in the matrix below indicate that the fit is superior for the sample of countries that can be classified as 
democracies.

$\left[\begin{array}{ccccc} & \text { Tariff } & \text { Quota } & \text { Imp Duty } & (X+M) / G D P \\ \text { Democracies } & 0.70 & 0.58 & 0.71 & 0.54 \\ \text { Dictatorships } & 0.18 & 0.25 & 0.35 & 0.23\end{array}\right]$

The comparisons are very similar with controls.

Finally, we run regressions with additional interaction terms (ideology*democracy and ide$\operatorname{olog} y *(K / L) *$ democracy $)^{35}$ to investigate the hypothesis (b) whether the demand for prolabor redistribution through trade policies is stronger in democracies or in dictatorships. Both the interaction terms are significant at the $5 \%$ level for tariffs, import duty and $(X+M) / G D P$ but not for the quota regressions. Here we find that in democracies the magnitude of the partisan effects are weaker. For the regression with controls, the cross-partial derivative is ${ }^{36}$

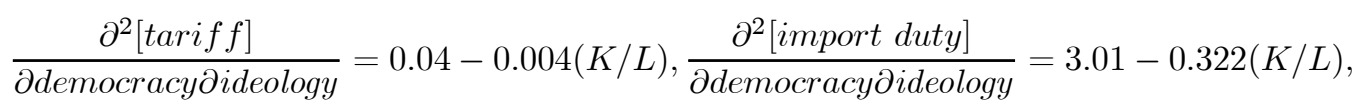

$$
\begin{aligned}
& \frac{\partial^{2}[(X+M) / G D P]}{\partial \text { democracy } \operatorname{ideology}}=-6.4+0.814(K / L)
\end{aligned}
$$

so that dictatorships reinforce the negative (positive) relationship between ideology and trade protection in capital scarce (abundant) countries, predicted by the partisan model. Even in these regressions the critical capital-labor ratio (where the relationship between ideology and trade protection switches from negative to positive) is close to the median capital-labor ratio.

Thus the partisan model fits the data better for democracies but the magnitude of the effects are smaller in democracies. Dictators who have consolidated their position may not face any electoral threats and may have fewer incentives to formulate trade policies according to their ideological affinities. However, if they do decide to favor their "core" constituent groups they are likely to face lesser constraints in implementing redistributive trade policies. Thus we may observe that the magnitude of partisan effect is larger in absolute terms even if the partisan model as a whole is a better fit for democracies.

\footnotetext{
35 Here we calculated the democracy variable as $(8-$ polrights $)$ for ease of interpretation.

36 The results are similar if we use regressions without controls.
} 


\subsection{Fractionalized vs. unified opposition}

Next we examined if the partisan model works better where there is a single unified opposition (such as a two-party system as in the US). A fractionalized opposition is likely to pose fewer threats to the ruling party/executive, giving them lesser incentives to consolidate their electoral base by pursuing partisan objectives. The more fragmented are opposition parties, the more difficult it is for them to cooperate strategically and pose a threat to the ruling party. For instance, Cox and Niou (1994) showed that a highly fractionalized opposition in Japan contributed to the consolidation of power by the ruling party (the Liberal Democratic Party) in Japan and explains its long tenure in power. DPI includes a variable that captures the extent of fractionalization of the opposition. This variable measures the probability that two random draws from all opposition legislators will produce members belonging to distinct parties. ${ }^{37}$

First, we divided our sample into those countries where opposition fractionalization is greater than 0.5 and those less than 0.5 and estimated separate models for each of these sub-samples. The partisan model seems to work for both unified and fractionalized oppositions. Even the critical capital-labor ratios seem indistinguishable. Second, we calculated the correlation between the predicted and actual values of protection for distinct samples (using the 0.5 opposition fractionalization value as the cutoff) much the same as we did for democracy and dictatorship. Again, there is no indication that the model fit is superior for either sample. Next, we generated and regressed the absolute value and the square of the residuals on opposition fractionalization. Only for the quota coverage ratio we find that the residuals are significantly higher in countries where the opposition parties are highly fractionalized. This suggests that at least for quotas, the partisan model better fits countries that have a unified opposition. Finally, we interacted opposition fractionalization with ideology and ideology $*(K / L)$. Only in the case of tariffs and import duty

\footnotetext{
37 Note that this probability is calculated and reported in the database only for countries that have parliaments or their equivalent. Thus, our regressions in this subsection are restricted to such countries.
} 
were these coefficients significant at the $5 \%$ level. The cross-partial derivative is as follows

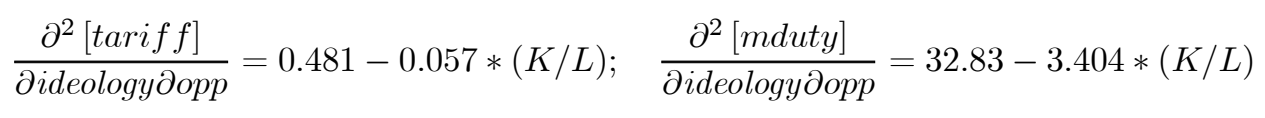

so we find that a fractionalized opposition weakens the effect of ideology on trade policies in both capital and labor abundant countries.

\subsection{Coalition vs. single-party governments}

We also investigated how the predictions of the partisan voter model fares in the presence of a coalition government. A single party government has been shown to be more stable (Taylor and Herman, 1971) and can pursue its goals and objectives more efficiently. A coalition government on the other hand may be constrained in the pursuit of its ideological objectives. We use data on government fractionalization to investigate this issue. However, we do not find any evidence that government fractionalization matters. The ideological model fits both single party and coalition

governments, and additional interaction terms of government fractionalization are individually and jointly insignificant. The only result we discover is that for $(X+M) / G D P$, when we regress the absolute values of the residuals on government fractionalization, the latter has a positive and significant coefficient at the $10 \%$ level. We cannot read too much into this since $(X+M) / G D P$ is an indirect measure of trade policy and may depend on a host of extraneous variables.

\section{Robustness Checks}

\subsection{International comparability of the DPI ideology measure}

It may be argued that the comparability of the ideology measure across nations is problematic. For instance, one may argue that a political party (and its ideology) that is regarded as left-wing in one country may be regarded as centrist or right-wing in another country. More precisely, leftist and rightist orientations may be relative to the center in each country where the center itself is country-specific. This could raise questions about the validity of our cross-sectional results. While a country-specific dummy (along with the instrumentation of the capital-labor ratio and its in- 
teraction with the ideology variable using the saving rate and the population growth rate) would take care of this criticism, this is clearly an impossible goal for the cross-sectional regressions. Accordingly, as a first robustness check, we created 9 very comprehensive region-specific dummies, ${ }^{38}$ since we consider it very plausible that countries from the same region have a common notion of a center around which party/government ideologies are classified. As before, we instrumented the capital-labor ratio and its interaction with the ideology variable. (The instrumentation of the product of $K / L$ and Ideology also corrects for the measurement error in this interaction term.) Our results remain qualitatively unchanged in terms of the sign and the significance of coefficients. Even the critical capital-labor ratio remains roughly in the same range, around 10.

As a second robustness check, we examined whether and how our results were altered after making certain adjustments to the data on political ideology. These adjustments reflect country and region specific variations in the ideology definition. Based on discussions with various regional experts, we decided to experiment with the following adjustments. We increased the magnitude of the scale, 1 being the most right-oriented and 5 the most left-oriented. For the US, the Republicans and Democrats remained at 1 and 3 respectively as before. For Latin America, right was recoded as 1 , center as 3 and left as 5 . The left-wing government of China was recoded as 5 . For Europe (excluding Ireland and the UK for which we retained the original coding), right, center and left were recoded as 2, 3 and 4 respectively. Again our results survive this adjustment. We experimented with a few other perturbations to the data on ideology as well. We did not find any substantial qualitative change in our results in terms of the signs of coefficients, their statistical significance and the critical capital-labor ratios.

We also verified the quality of the DPI ideology measure by checking whether it was a good predictor of inequality after controlling for the Kuznets effect (captured by the per capita GDP and its square). We found a negative and highly significant coefficient for the ideology variable.

\footnotetext{
38 For our region-specifc effects we use the following regional categories: East Asia, Rest of Asia, Oceania, Eastern Europe, Western Europe, North America, Latin America (excluding Mexico), Oil producing countries and Africa.
} 
Since the Kuznets effect is a long-run relationship, and since our data are decade-wide averages, we believe that finding this relationship clearly shows that our measures are fairly comparable across countries. We also find that the ideology measure is a good predictor of public health and education expenditure as a proportion of GDP after controlling for per capita GDP which can be seen from the following regression:

$$
H E=\underset{(0.61)}{4.46^{* * *}}+\underset{(0.06)}{0.48^{* * *}} \ln (G D P \text { per capita })+\underset{(0.10)}{0.23^{* * *}} \text { Ideology, } R^{2}=0.47
$$

where $H E$ is the combined measure (using the principal-components method) ${ }^{39}$ of the healthGDP and education-GDP ratios. Adding a square term in per capita GDP leaves the sign, significance and even the magnitude of the coefficient estimate of ideology unchanged. We also experimented with a measure constructed (again using the principal-components analysis) with the residuals from the regressions of the health-GDP and education-GDP ratios on per capita GDP. This measure, which we denote as HER, can be considered to be a very rough measure of the revealed leftist orientation of the government. Using this measure instead of ideology, we were able to obtain the following result :

$$
\text { Tariff }=\underset{(0.10)}{0.59^{* * *}}-\underset{(0.01)}{0.05^{* * *}}(K / L)-\underset{(0.10)}{0.279^{* * *}} H E R+\underset{(0.01)}{0.024^{* * *}} H E R *(K / L), R^{2}=0.46
$$

In the above regression, the coefficients of HER and its interaction with the K/L ratio have the signs predicted by our theory. In addition, we cannot reject the hypothesis even at the $15 \%$ level of significance that the critical capital-labor ratio equals the median capital-labor ratio.

\subsection{Controlling for the endowments of other factors of production}

Next we control for the size of the endowment of land. We introduce the land-labor ratio and the interaction of ideology and the land-labor ratio as additional variables. Our original results with

\footnotetext{
${ }^{39}$ We created a linear composite of the two variables - health and education expenditure as a percentage of GDP. Only components whose eigenvalues were greater than one were retained. This led to a single principal component being retained, which accounts for $79 \%$ of the variation in the two variables. The weights used were the eigenvectors associated with the eigenvalues of the correlation matrix of these two variables.
} 
respect to capital-labor ratio and its interaction with ideology remain qualitatively unaffected. For example, for the tariff measure we have

$$
\begin{aligned}
\text { Tariff } & =\underset{(0.30)}{1.59} 9^{* * *}-\underset{(0.03)}{0.13^{* * *}}(K / L)+\underset{(0.02)}{0.05} 5^{* * *}(T / L)-\underset{(0.12)}{0.43^{* * *}} \text { Ideology } \\
& +\underset{(0.01)}{0.035^{* * *}} \operatorname{Ideolog} y(K / L)-\underset{(0.01)}{0.02} 2^{* * *} \operatorname{Ideolog} y(T / L) \\
N & =64, R^{2}=0.39
\end{aligned}
$$

Note that $T / L$ denotes the land-labor ratio in natural $\operatorname{logs}$ (and is negative for most countries), while $K / L$ as before is the capital-labor ratio in natural logs. Computing the derivative of the tariff measure with respect to ideology from the above regression results in a fairly even split between countries with a negative derivative and those with a positive derivative. However, the derivative moves in opposite directions with respect to capital abundance and land abundance. While for capital-abundant (capital-scarce) countries, there is a tendency for countries to be more protectionist (open) as the government becomes more left-oriented, the reverse is the case with land-abundance. This goes to show that the government's weight on land relative to other factors combined generally increases as the government becomes more left-oriented. ${ }^{40}$ For all our direct protection measures (tariff, quota and import duty), we get these results with the same signs and with very similar statistical significance and magnitudes, while for our indirect measure $(X+M) / G D P$, some of the coefficient estimates are not statistically significant. We also run several regressions where we include only the capital-land ratio and its interaction with the ideology variable (in addition to the ideology variable itself) and some others where we have the land-labor ratio in place of the capital-labor ratio. All these regressions seem to indicate that there is a possibility that land and labor tend to form coalitions against capital and that left-wing

\footnotetext{
40 We also tried inserting separately capital, labor and land (in place of the land-labor and capital-labor ratios) and their interactions. We did not find these variables to be individually significant even though they were highly significant jointly. Since we measure all the factors in logs, the version with land-labor and capital-labor ratios is a special case of the version with land, labor and capital. In fact, we are unable to reject the joint restrictions that give us this special case.
} 
governments tend to place a higher weight on land-labor coalitions relative to capital than do right-wing ones.

Finally, instead of using the capital-labor ratio and/or the land-labor ratio in the regressions, we use the per capita GDP (by itself and its interaction with ideology). The results are very similar to the ones obtained with the $K / L$ ratio, thereby indicating that in countries that are abundant (scarce) in productive assets, a more left wing (right wing) government raises protection. This seems to be more or less true with all our direct protection measures. For example, for our tariff measure we have

$$
\begin{aligned}
\text { Tarif } f & =\underset{(0.19)}{1.05^{* * *}}-\underset{(0.08)}{0.2}{ }^{* * *} \text { Ideology } \\
N & =63, R^{2}=0.02^{* * *}=01 \text { Ideology }(\text { per capitaGDP })-\underset{(0.02)}{0.1}
\end{aligned}
$$

\section{Conclusion}

In this paper, we empirically investigate how the ideology of the government in power affects trade policy. Government's ideology is a combination of the preferences of their constituent groups that vote for them and provide them with political contributions, as well as, their beliefs about what is good for the country's citizens. The prediction of such a partisan, ideology-based model (within a two-sector, two-factor Heckscher-Ohlin framework) is that left-wing governments will adopt more protectionist trade policies in capital rich countries, but adopt more pro-trade policies in labor rich economies. The data strongly support this prediction in a very robust fashion. There is some evidence, that this relationship may hold better in democracies than in dictatorships though the magnitude of the partisan effect seems stronger in dictatorships. We also find that while fractionalization within the government does not seem to matter much, the fractionalization of the opposition does matter. Our results suggest that partisan considerations are more important in the presence of a unified opposition.

Of late, economic policy reforms that foster growth, reduce inequality and alleviate poverty 
have been attracting increasing attention from both academicians and policymakers. Simultaneously, there is a growing recognition that political institutions matter for these economic goals as well. To design effective economic policies to achieve these goals, it is critical that we have a thorough understanding of the interrelationship between policy variables and political institutions. While the theoretical and empirical results in this paper are positive rather than normative, this paper takes a step in this direction by delineating the role of political ideology for trade policies.

\section{References}

Alesina, A., 1987, "Macroeconomic Policy in a Two Party System as a Repeated Game," Quarterly Journal of Economics 102, 651-678.

Alesina, A. and Roubini, N., 1992, "Political Cycles in OECD Economies," Review of Economic Studies 59, 663-688.

Alt, J., 1985, "Political Parties, World Demand and Unemployment: Domestic and International Sources of Economic Activity," American Political Science Review 79, 1016-1040.

Alt, J., 1986, "Party Strategies, World Demand, and Unemployment: The Political Economy of Economic Activity in Western Industrial Nations," American Economic Review (AEA Papers 8 Proceedings) 76(2), 57-61.

Baldwin, R. and C. Magee, 1998, "Is Trade Policy for Sale? Congressional Voting on Recent Trade Bills," NBER Working Paper \# 6376.

Balistreri, E., 1997, "The Performance of the Heckscher-Ohlin-Vanek Model in Predicting Endogenous Policy Forces at the Individual Level," Canadian Journal of Economics 30(1), $1-17$.

Beaulieu, E., 2000, "The Stolper-Samuelson Theorem Faces Congress," Review of International Economics, forthcoming.

Beaulieu, E., 2001, "Factor or Industry Cleavages in Trade Policy? An Empirical Analysis of the Stolper-Samuelson Theorem," mimeo, Department of Economics, University of Calgary

Beaulieu, E. and C. Magee, 2000, "Campaign Contributions and Trade Policy: Simple Tests of Stolper-Samuelson," mimeo, Department of Economics, University of Calgary and Department of Economics, Bard College.

Beck, T; Clarke, G; Groff, A. and P. Keefer, 2001, "New Tools and New Tests in Comparative Political Economy: The Database of Political Institutions," forthcoming, World Bank Economic Review.

Cox, Gary W. and Emerson Niou. 1994. "Seat Bonuses under the Single Non-Transferable Vote System: Evidence from Japan and Taiwan," Comparative Politics, 26(2), pp. 221-236.

Downs, Arthur, 1957, An Economic Theory of Democracy, New York: Harper Collins, 1957.

Fernandez, R. and D. Rodrik, 1991, "Resistance to Reform: Status-Quo Bias in the Presence of Individual-Specific Uncertainty," American Economic Review 81(5), 1146-1155. 
Feenstra, R. and J. Bhagwati, 1982, "Tariff Seeking and the Efficient Tariff," in: J. Bhagwati, ed., Import competition and response (The University of Chicago Press).

Findlay, R. and S. Wellisz, 1982, "Endogenous tariffs, the political economy of trade restrictions and welfare," in: J.N. Bhagwati, ed., Import competition and response (The University of Chicago Press), 223-234.

Gawande, K. and P. Krishna, 2001, "The Political Economy of Trade Policy: Empirical Approaches," in J. Harrigan (ed.), Handbook of International Economics, forthcoming.

Gawande, K. and U. Bandopadhyay, 2000, "Is Protection for Sale? A Test of the GrossmanHelpman Theory of Endogenous Protection," Review of Economics \& Statistics 82(1), 139152.

Glazer, A and B. Grofman, 1989, "Why Representatives are Ideologists though Voters are not," Public Choice 61(1), 29-39.

Goldberg, P. and G. Maggi, 1999, "Protection for Sale: An Empirical Investigation," American Economic Review 89(5), 1135-1155.

Grossman, G. and E. Helpman, 1994, "Protection for Sale," American Economic Review, September 1994, 833-850.

Harrigan, J., 1993, OECD Imports and Trade Barriers in 1983, Journal of International Economics 35(1), 91-111.

Helpman, E., 1997, "Politics and Trade Policy," in D. Kreps and K. Wallis (eds.), Advances in Economics and Econometrics: Theory and Applications, Volume II, Cambridge University Press (Cambridge, UK).

Hibbs, D., 1977, "Political Parties and Macroeconomic Policy," The American Political Science Review 7, 1467-1487.

Hibbs, D. and N. Vasilatos, 1982, "Economic Outcomes and Political Support for British Governments among Occupational Classes: A Dynamic Analysis, "The American Political Science Review, 76(2), 259-279.

Hibbs, D.; Rivers, D. and N. Vasilatos, 1982, "The Dynamics of Political Support for American Presidents Among Occupational and Partisan Groups," American Journal of Political Science, 26(2), 312-332.

Hillman, A., 1989, The Political Economy of Protection (Harwood Academic, London and New York), 1989.

Irwin, D., 1994, "The Political Economy of Free Trade: Voting in British General Election of 1906," Journal of Law and Economics 37, 75-108.

Irwin, D., 1996, "Industry or Class Cleavages over Trade Policy? Evidence from the British General Election of 1923," in: R. Feenstra, G. Grossman and D. Irwin, eds., The Political Economy of Trade Policy: Papers in Honor of Jagdish Bhagwati (MIT Press, Cambridge, MA), 53-75.

Kahane, L., 1996, "Congressional Voting Patterns on NAFTA; An Empirical Analysis," American Journal of Economics and Sociology 55, 395-409.

Kalt, J. and M. Zupan, 1984, "Capture and Ideology in the Economic Theory of Politics," American Economic Review 74(3), 279-300. 
Kau, J. and P. Rubin, 1979, "Self Interest, Ideology and Logrolling in Congressional Voting," Journal of Law and Economics 22(2), 365-384.

Leamer, E., 1990, "The Structure and Effects of Tariff and Non-tariff Barriers" in 1983, in: R. Jones and A. Krueger, eds., The Political Economy of International Trade: Essays In Honor of Robert E. Baldwin (Basil Blackwell, Cambridge, MA), 224-260.

Leamer, E. and J. Levinsohn, 1995, "International Trade Theory: The Evidence," in: G. Grossman and K. Rogoff, eds,. Handbook of International Economics, Vol. 3. Amsterdam: North-Holland, 1339-94.

Magee, S., 1978, "Three Simple Tests of the Stolper-Samuelson Theorem," in: P. Oppenheimer, ed., Issues in International Economics (Oriel Press, Stockfield).

Magee, S., Brock, W., and L. Young, 1989, Black Hole Tariffs and Endogenous Policy Theory (Cambridge University Press, Cambridge and New York).

Mansfield, E. and M. Busch, 1995, "The Political Economy of Nontariff Barriers: A CrossNational Analysis," International Organization 49(4), 723-49.

Mayer, Wolfgang. "Endogenous Tariff Formation." American Economic Review, December 1984, 74(5), pp. 970-85.

Mitra, D., 1999, "Endogenous Lobby Formation and Endogenous Protection: A Long Run Model of Trade Policy Determination," American Economic Review 89(5), 1116-1134.

Peltzman, S., 1984, "Constituent Interest and Congressional Voting," Journal of Law and Economics 27(2), 181-210.

Persson, T and Tabellini, G. 2000, Political Economics: Explaining Economic Policy MIT Press, August 2000.

Rodrik, D., 1986, "Tariffs, Subsidies, and Welfare with Endogenous Policy," Journal of International Economics, November 1986, 21(3/4), 285-299.

Rodrik, D., 1995, "Political Economy of Trade Policy," in: G. Grossman and K. Rogoff, eds,. Handbook of International Economics, Vol. 3. Amsterdam: North-Holland, 1457-1494.

Rodrik, D., 1997, Has Globalization Gone Too Far?, (Institute for International Economics, Washington, D.C.).

Rogowski, R., 1987, "Political Cleavages and Changing Exposure to Trade," American Political Science Review 81(4), 1121-1137.

Sachs, Jeffrey D. and Warner, Andrew M., 1995, "Economic Reform and the Process of Global Integration", Brookings Papers on Economic Activity, 1, pp. 1-118.

Scheve, K. and M. Slaughter, 2001, "What Determines Individual Trade Policy Preferences?," Journal of International Economics, 54(2), pp. 267-292.

Steagall, J. and K. Jennings, 1996, "Unions, PAC Contributions and the NAFTA Vote," Journal of Labor Research 17, 515-521.

Taylor, Michael and Herman, V.M., 1971, "Party Systems and Governmental Instability," American Political Science Review, 56, March: pp. 28-37.

Trefler, D., 1993, "Trade Liberalization and the Theory of Endogenous Protection," Journal of Political Economy 101, 138-160. 


\begin{tabular}{|lcccccc|}
\hline & Table 0.1: Summary & Statistics & \\
Variable & Obs & Mean & Std. Dev. & Min & Max \\
tariff & 67 & 0.15 & 0.12 & 0.01 & 0.48 \\
quota coverage ratio & 66 & 0.19 & 0.24 & 0 & 0.87 \\
import duty (1980-89, avg.) & 65 & 10.31 & 8.29 & 0.01 & 29.78 \\
(X+M)/GDP & 88 & 33.27 & 30.06 & 4.51 & 171.01 \\
log capital-labor ratio (Easterly-Levine, agg) & 92 & 9.36 & 1.54 & 5.71 & 11.43 \\
ideology (1=Right, 2=Center, 3=Left) & 92 & 2.11 & 0.83 & 1 & 3 \\
govt. fractionalization & 82 & 0.18 & 0.27 & 0 & 1 \\
opposition fractionalization & 70 & 0.44 & 0.23 & 0 & 1 \\
dictatorship (Gastil) & 91 & 3.58 & 2.20 & 1 & 7 \\
log of savings rate & 85 & 2.77 & 0.82 & -1.95 & 3.72 \\
log of population growth rate & 90 & 0.15 & 1.06 & -3.47 & 1.25 \\
& & & & & \\
Panel Variables (1980-1989) & & & & & \\
import duty & Obs & Mean & Std. Dev. & Min & Max \\
(X+M)/GDP & 670 & 9.46 & 7.62 & 0 & 39.77 \\
ideology & 730 & 35.70 & 38.52 & 4.03 & 570.87 \\
log capital-labor ratio (Easterly-Levine, agg) & 820 & 2.11 & 0.94 & 1 & 3 \\
& 820 & 9.48 & 1.52 & 5.63 & 11.52 \\
\hline
\end{tabular}

Table 0.2: Correlation Matrix for measures of protection

$\begin{array}{ccccc} & \text { Tariff } & \text { Quota } & \text { mport Duts(X+M)/GDP } \\ \text { Tariff } & 1 & & & \\ \text { Quota } & 0.2969 & 1 & & \\ \text { Import Duty } & 0.7203 & 0.2663 & 1 & \\ (\boldsymbol{X}+\mathbf{M}) \text { /GDP } & -0.4615 & -0.2584 & -0.3596 & 1\end{array}$




\begin{tabular}{|c|c|c|c|c|c|c|c|c|}
\hline & \multicolumn{7}{|c|}{ Table 1: Easterly-Levine (aggregate)- Regression with dummies } & \multirow[b]{3}{*}{$(X+M) / G D P$} \\
\hline & \multicolumn{4}{|c|}{ Left vs. Non-Left } & \multicolumn{3}{|c|}{ Left \& Center vs. Right } & \\
\hline & Tariff & Quota & Import Duty & $(X+M) / G D P$ & Tariff & Quota & Import Duty & \\
\hline \multirow[t]{2}{*}{ left } & $-0.574^{\star * *}$ & $-1.225^{\star \star \star}$ & -12.075 & $114.692^{\star \star *}$ & $-0.734^{* \star *}$ & $-1.51^{* \star *}$ & -13.189 & $75.762^{*}$ \\
\hline & $(0.181)$ & $(0.477)$ & $(10.204)$ & $(48.577)$ & $(0.194)$ & $(0.553)$ & $(11.507)$ & $(49.907)$ \\
\hline \multirow[t]{2}{*}{ left ${ }^{*}$ capital-labor ratio } & $0.055^{\star * *}$ & $0.115^{\star * *}$ & 1.247 & $-11.914^{* * *}$ & $0.072^{* * *}$ & $0.142^{* * *}$ & 1.365 & $-7.972^{*}$ \\
\hline & $(0.017)$ & $(0.045)$ & $(1.011)$ & $(5.183)$ & $(0.018)$ & $(0.053)$ & $(1.17)$ & $(5.441)$ \\
\hline \multirow[t]{2}{*}{ center } & & & & & -0.365 & $-1.526^{* * *}$ & -4.092 & $-164.819^{*}$ \\
\hline & & & & & $(0.373)$ & $(0.644)$ & (24.58) & $(111.235)$ \\
\hline \multirow[t]{2}{*}{ center ${ }^{*}$ capital-labor ratio } & & & & & 0.039 & $0.141^{\star \star \star}$ & 0.406 & 15.904 \\
\hline & & & & & $(0.034)$ & $(0.06)$ & $(2.287)$ & $(11.451)$ \\
\hline \multirow[t]{2}{*}{ capital-labor ratio } & $-0.08^{\star \star \star}$ & $-0.116^{\star \star *}$ & $-3.645^{\star \star \star}$ & $18.432^{\star * \star}$ & $-0.097^{\star \star *}$ & $-0.143^{\star * \star}$ & $-3.762^{\star * *}$ & $14.49^{\star * \star}$ \\
\hline & $(0.014)$ & $(0.042)$ & $(0.736)$ & $(4.974)$ & $(0.016)$ & $(0.05)$ & $(0.934)$ & $(5.237)$ \\
\hline \multirow[t]{2}{*}{ constant } & $0.952^{* * *}$ & $1.391^{\star * *}$ & $45.217^{\star \star \star}$ & $-144.551^{* * *}$ & $1.112^{* * *}$ & $1.676^{\star * *}$ & $46.331^{* * *}$ & $-105.621^{* * *}$ \\
\hline & $(0.155)$ & $(0.45)$ & $(7.604)$ & $(47.31)$ & $(0.169)$ & $(0.529)$ & $(9.194)$ & $(48.644)$ \\
\hline No. of observations & 67 & 66 & 65 & 88 & 67 & 66 & 65 & 88 \\
\hline$R^{2}$ & 0.32 & 0.15 & 0.35 & 0.32 & 0.34 & 0.19 & 0.35 & 0.35 \\
\hline F-statistic & $14.07^{* * *}$ & $2.7^{* \star *}$ & $12.9^{* * *}$ & $13.88^{* * *}$ & $12.6^{\star * *}$ & $1.8^{*}$ & $7.58^{* \star *}$ & $8.45^{* * *}$ \\
\hline critical capital-labor ratio & 10.4 & 10.6 & 9.7 & 9.6 & & & & \\
\hline Joint test for cardinality (F-statistic) & & & & & 0.38 & 0.62 & 0.55 & $1.32^{*}$ \\
\hline \multicolumn{9}{|c|}{ Standard errors in parantheses; ${ }^{* \star *}$ - significant at $5 \%$ level, ${ }^{* *}$ - significant at $10 \%$ level ${ }^{*}$ - significant at $15 \%$ level } \\
\hline
\end{tabular}




\begin{tabular}{|c|c|c|c|c|c|c|c|c|}
\hline & \multicolumn{8}{|c|}{ Table 2: Easterly-Levine (aggregate)- Regression with and without controls } \\
\hline & Tariff & Quota & Import Duty & $(X+M) / G D P$ & Tariff & Quota & Import Duty & $(X+M) / G D P$ \\
\hline ideology & $\begin{array}{c}-0.394^{\star * *} \\
(0.095)\end{array}$ & $\begin{array}{c}-0.783^{* * *} \\
(0.263)\end{array}$ & $\begin{array}{c}-10.011^{*} \\
(6.22)\end{array}$ & $\begin{array}{c}58.493^{* * *} \\
(25.975)\end{array}$ & $\begin{array}{l}-0.36^{* * *} \\
(0.113)\end{array}$ & $\begin{array}{l}-0.93^{\star \star \star} \\
(0.307)\end{array}$ & $\begin{array}{c}-9.938^{*} \\
(6.49)\end{array}$ & $\begin{array}{l}47.005^{\star *} \\
(25.921)\end{array}$ \\
\hline ideology*capital-labor ratio & $\begin{array}{l}0.04^{* * *} \\
(0.009)\end{array}$ & $\begin{array}{c}0.073^{\star \star \star} \\
(0.025)\end{array}$ & $\begin{array}{l}1.043^{*} \\
(0.652)\end{array}$ & $\begin{array}{c}-6.209^{\star * *} \\
(2.819)\end{array}$ & $\begin{array}{c}0.035^{\star * *} \\
(0.011)\end{array}$ & $\begin{array}{c}0.087^{\star * *} \\
(0.029)\end{array}$ & $\begin{array}{l}1.027^{*} \\
(0.679)\end{array}$ & $\begin{array}{l}-4.857^{\star *} \\
(2.806)\end{array}$ \\
\hline capital-labor ratio & $\begin{array}{c}-0.138^{\star * *} \\
(0.023)\end{array}$ & $\begin{array}{c}-0.221^{* * *} \\
(0.07)\end{array}$ & $\begin{array}{c}-5.327^{\star * *} \\
(1.543)\end{array}$ & $\begin{array}{c}25.228^{\star * *} \\
(8.022)\end{array}$ & $\begin{array}{c}-0.138^{* * *} \\
(0.025)\end{array}$ & $\begin{array}{c}-0.253^{\star * *} \\
(0.076)\end{array}$ & $\begin{array}{c}-5.014^{\star \star *} \\
(1.53)\end{array}$ & $\begin{array}{c}23.041^{\star \star \star} \\
(7.988)\end{array}$ \\
\hline political rights (Gastil) & & & & & $\begin{array}{c}0.003 \\
(0.009)\end{array}$ & $\begin{array}{l}-0.001 \\
(0.02)\end{array}$ & $\begin{array}{l}-0.216 \\
(0.604)\end{array}$ & $\begin{array}{l}-3.8^{* * *} \\
(1.224)\end{array}$ \\
\hline sub-saharan africa & & & & & $\begin{array}{l}-0.054 \\
(0.063)\end{array}$ & $\begin{array}{c}0.031 \\
(0.127)\end{array}$ & $\begin{array}{c}2.353 \\
(3.016)\end{array}$ & $\begin{array}{c}21.47^{\star \star \star} \\
(7.972)\end{array}$ \\
\hline east asia & & & & & $\begin{array}{l}-0.067 \\
(0.043)\end{array}$ & $\begin{array}{c}-0.238^{\star *} \\
(0.136)\end{array}$ & $\begin{array}{c}1.694 \\
(2.506)\end{array}$ & $\begin{array}{c}5.671 \\
(5.006)\end{array}$ \\
\hline No. of observations & 67 & 66 & 65 & 88 & 66 & 65 & 64 & 87 \\
\hline$R^{2}$ & 0.34 & 0.2 & 0.36 & 0.31 & 0.38 & 0.25 & 0.36 & 0.4 \\
\hline F-statistic & $22.47^{\star \star \star}$ & $3.52^{* \star \star}$ & $12.31^{* * *}$ & $11.22^{* \star *}$ & $11.34^{\star * *}$ & $2.06^{\star * *}$ & $6.48^{\star * \star}$ & $7.47^{\star * *}$ \\
\hline critical capital-labor ratio & 9.9 & 10.7 & 9.6 & 9.4 & 10.3 & 10.7 & 9.7 & 9.7 \\
\hline
\end{tabular}




\begin{tabular}{|c|c|c|c|c|c|c|c|c|}
\hline \multirow[b]{3}{*}{ ideology } & \multicolumn{8}{|c|}{ Table 3: Easterly-Levine (disaggregated)- Regression with and without controls } \\
\hline & Tariff & Quota & Import Duty & $(X+M) / G D P$ & Tariff & Quota & Import Duty & $(X+M) / G D P$ \\
\hline & $\begin{array}{c}-0.392^{* * *} \\
(0.165)\end{array}$ & $\begin{array}{c}-0.996^{* * *} \\
(0.514)\end{array}$ & $\begin{array}{c}-9.448 \\
(11.526)\end{array}$ & $\begin{array}{l}91.587^{* *} \\
(47.726)\end{array}$ & $\begin{array}{c}-0.392^{* * *} \\
(0.166)\end{array}$ & $\begin{array}{c}-1.634^{* * *} \\
(0.438)\end{array}$ & $\begin{array}{c}-12.703 \\
(9.178)\end{array}$ & $\begin{array}{c}66.465 \\
(48.571)\end{array}$ \\
\hline ideology ${ }^{*}$ capital-labor ratio & $\begin{array}{c}0.042^{\star * *} \\
(0.017)\end{array}$ & $\begin{array}{l}0.095^{\star *} \\
(0.051)\end{array}$ & $\begin{array}{c}0.98 \\
(1.179)\end{array}$ & $\begin{array}{c}-10.144^{\star \star} \\
(5.293)\end{array}$ & $\begin{array}{c}0.041^{* * *} \\
(0.017)\end{array}$ & $\begin{array}{c}0.157^{\star * *} \\
(0.044)\end{array}$ & $\begin{array}{c}1.245 \\
(0.954)\end{array}$ & $\begin{array}{l}-7.401 \\
(5.373)\end{array}$ \\
\hline capital-labor ratio & $\begin{array}{c}-0.154^{\star * *} \\
(0.037)\end{array}$ & $\begin{array}{c}-0.277^{\star *} \\
(0.147)\end{array}$ & $\begin{array}{c}-6.498^{* * *} \\
(2.832)\end{array}$ & $\begin{array}{l}38.141^{\star \star \star} \\
(14.502)\end{array}$ & $\begin{array}{c}-0.129^{\star \star *} \\
(0.047)\end{array}$ & $\begin{array}{c}-0.389^{\star \star *} \\
(0.156)\end{array}$ & $\begin{array}{c}-4.795^{\star \star} \\
(2.692)\end{array}$ & $\begin{array}{c}33.349^{* \star *} \\
(14.879)\end{array}$ \\
\hline political rights (Gastil) & & & & & $\begin{array}{c}0.008 \\
(0.013)\end{array}$ & $\begin{array}{c}-0.009 \\
(0.03)\end{array}$ & $\begin{array}{c}0.368 \\
(0.708)\end{array}$ & $\begin{array}{c}-5.608^{\star * *} \\
(1.784)\end{array}$ \\
\hline sub-saharan africa & & & & & $\begin{array}{c}0.073 \\
(0.075)\end{array}$ & $\begin{array}{c}0.303^{\star \star *} \\
(0.128)\end{array}$ & $\begin{array}{c}9.142^{\star \star *} \\
(4.368)\end{array}$ & $\begin{array}{l}28.573^{* *} \\
(16.101)\end{array}$ \\
\hline east asia & & & & & $\begin{array}{c}0.034 \\
(0.051)\end{array}$ & $\begin{array}{c}-0.352^{\star *} \\
(0.191)\end{array}$ & $\begin{array}{l}-0.337 \\
(2.074)\end{array}$ & $\begin{array}{c}13.598^{\star *} \\
(7.968)\end{array}$ \\
\hline oil & & & & & $\begin{array}{c}0.086^{* * *} \\
(0.032)\end{array}$ & $\begin{array}{c}-0.093^{* *} \\
(0.05)\end{array}$ & $\begin{array}{c}6.068^{* * *} \\
(1.674)\end{array}$ & $\begin{array}{c}-24.318^{\star * *} \\
(7.587)\end{array}$ \\
\hline constant & $\begin{array}{l}1.588^{\star * *} \\
(0.369)\end{array}$ & $\begin{array}{c}3.005^{\star * *} \\
(1.499)\end{array}$ & $\begin{array}{c}70.507^{\star * *} \\
(28.044)\end{array}$ & $\begin{array}{l}-313.06^{\star * *} \\
(133.005)\end{array}$ & $\begin{array}{l}1.315^{\star * \star} \\
(0.488)\end{array}$ & $\begin{array}{c}4.166^{\star \star *} \\
(1.604)\end{array}$ & $\begin{array}{l}53.413^{\star *} \\
(27.268)\end{array}$ & $\begin{array}{c}-258.669^{* *} \\
(137.695)\end{array}$ \\
\hline No. of observations & 37 & 36 & 38 & 44 & 36 & 35 & 37 & 43 \\
\hline$R^{2}$ & 0.43 & 0.3 & 0.45 & 0.28 & 0.46 & 0.5 & 0.55 & 0.39 \\
\hline F-statistic & $11.8^{\star * \star}$ & $2.83^{* *}$ & $7.63^{\star \star \star}$ & $4.93^{\star \star *}$ & $18.79^{\star \star \star}$ & $11.08^{\star * \star}$ & $14.18^{\star * *}$ & $4.39^{\star \star \star}$ \\
\hline critical capital-labor ratio & 9.3 & 10.5 & 9.6 & 9 & 9.6 & 10.4 & 10.2 & 9 \\
\hline
\end{tabular}




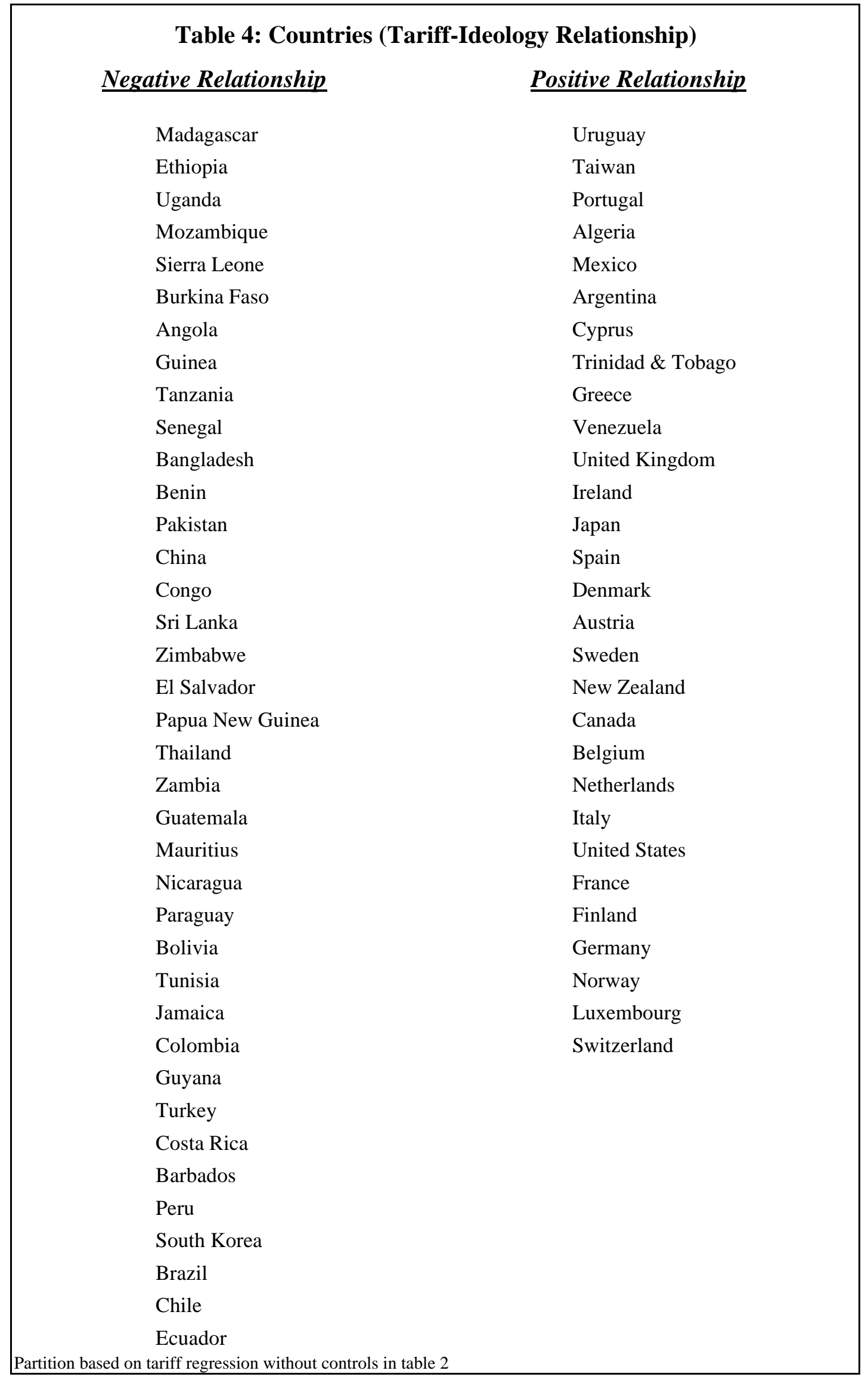




\begin{tabular}{|c|c|c|c|c|c|c|c|c|}
\hline & \multicolumn{8}{|c|}{ Table 5: Easterly-Levine (aggregate)- 2 SLS Regression cardinal and ordinal } \\
\hline & \multicolumn{4}{|c|}{ Cardinal Interpretation } & \multicolumn{4}{|c|}{ Ordinal Interpretation } \\
\hline & Tariff & Quota & Import Duty & $(X+M) / G D P$ & Tariff & Quota & Import Duty & $(X+M) / G D P$ \\
\hline ideology & $\begin{array}{c}-1.057^{* * *} \\
(0.417)\end{array}$ & $\begin{array}{c}-1.493^{* * *} \\
(0.581)\end{array}$ & $\begin{array}{c}-45.591^{* * *} \\
(19.793)\end{array}$ & $\begin{array}{c}165.015^{* * *} \\
(73.004)\end{array}$ & & & & \\
\hline ideology*capital-labor ratio & $\begin{array}{c}0.109^{* * *} \\
(0.044)\end{array}$ & $\begin{array}{c}0.147^{* * *} \\
(0.061)\end{array}$ & $\begin{array}{c}4.773^{* * *} \\
(2.133)\end{array}$ & $\begin{array}{c}-17.23^{* * *} \\
(7.739)\end{array}$ & & & & \\
\hline capital-labor ratio & $\begin{array}{c}-0.315^{\star * *} \\
(0.107)\end{array}$ & $\begin{array}{l}-0.41^{* \star *} \\
(0.153)\end{array}$ & $\begin{array}{c}-15.795^{\star * *} \\
(4.963)\end{array}$ & $\begin{array}{c}55.277^{* * *} \\
(19.917)\end{array}$ & $\begin{array}{c}-0.214^{* * *} \\
(0.058)\end{array}$ & $\begin{array}{c}-0.312^{* * *} \\
(0.107)\end{array}$ & $\begin{array}{c}-11.177^{* * *} \\
(3.520)\end{array}$ & $\begin{array}{c}35.183^{* * *} \\
(12.180)\end{array}$ \\
\hline left & & & & & $\begin{array}{c}-2.141^{* * *} \\
(0.658)\end{array}$ & $\begin{array}{c}-3.267^{* * *} \\
(1.292)\end{array}$ & $\begin{array}{c}-90.469^{\star * *} \\
(41.017)\end{array}$ & $\begin{array}{c}285.685^{\star * *} \\
(142.102)\end{array}$ \\
\hline left ${ }^{*}$ capital-labor ratio & & & & & $\begin{array}{c}0.218^{* * *} \\
(0.067)\end{array}$ & $\begin{array}{c}0.321^{* * *} \\
(0.135)\end{array}$ & $\begin{array}{c}9.396^{* * *} \\
(4.291)\end{array}$ & $\begin{array}{c}-29.445^{\star * *} \\
(14.895)\end{array}$ \\
\hline center & & & & & $\begin{array}{l}-1.456 * \\
(0.956)\end{array}$ & $\begin{array}{c}-4.062^{* * *} \\
(1.332)\end{array}$ & $\begin{array}{l}-61.115 \\
(62.491)\end{array}$ & $\begin{array}{c}208.762 \\
(228.266)\end{array}$ \\
\hline center ${ }^{*}$ capital-labor ratio & & & & & $\begin{array}{l}0.150^{* *} \\
(0.092)\end{array}$ & $\begin{array}{c}0.393^{* * *} \\
(0.131)\end{array}$ & $\begin{array}{c}6.390 \\
(6.072)\end{array}$ & $\begin{array}{l}-20.899 \\
(22.003)\end{array}$ \\
\hline constant & $\begin{array}{c}3.239^{* * *} \\
(1.034)\end{array}$ & $\begin{array}{c}4.347^{* * *} \\
(1.504)\end{array}$ & $\begin{array}{l}162.79^{* * *} \\
(47.407)\end{array}$ & $\begin{array}{c}-501.897^{* * *} \\
(192.246)\end{array}$ & $\begin{array}{c}2.266^{* * *} \\
(0.583)\end{array}$ & $\begin{array}{c}3.333^{* * *} \\
(1.074)\end{array}$ & $\begin{array}{c}118.340^{* * *} \\
(34.296)\end{array}$ & $\begin{array}{c}-309.886^{* * *} \\
(119.224)\end{array}$ \\
\hline No. of observations & 64 & 63 & 62 & 79 & 64 & 63 & 62 & 79 \\
\hline$R^{2}$ & 0.27 & 0.18 & 0.3 & 0.26 & 0.25 & 0.17 & 0.25 & 0.24 \\
\hline F-statistic & $9.75^{\star * *}$ & $3.93^{* * *}$ & $16.74^{* * *}$ & $13.07^{* * *}$ & $4.48^{* * *}$ & $2.65^{\star \star \star}$ & $6.88^{* * *}$ & $6.25^{\star * *}$ \\
\hline critical capital-labor ratio & 9.7 & 10.2 & 9.6 & 9.6 & & & & \\
\hline $\begin{array}{l}\text { The R-square's reported in this tabl } \\
\text { The instruments used for the cardin } \\
\text { egression the squares and the cros } \\
\text { Standard errors in parentheses: }\end{array}$ & $\begin{array}{l}\text { e are the co } \\
\text { al regressio } \\
\text { ss product } 0 \\
\text { nificant at } 5\end{array}$ & $\begin{array}{l}\text { efficients of } \\
\text { ns are the } n \\
f \text { the log of } \\
\% \text { level, }{ }^{* *}-s\end{array}$ & $\begin{array}{l}\text { determination } \\
\text { latural logs of th } \\
\text { saving rate and } \\
\text { ignificant at } 10 \%\end{array}$ & $\begin{array}{l}\text { etween the ac } \\
\text { saving rate } \\
\text { he population } \\
\text { evel * - significe }\end{array}$ & $\begin{array}{l}\text { nd the pre } \\
\text { e populat } \\
\text { th rate ar } \\
5 \% \text { level }\end{array}$ & $\begin{array}{l}\text { d values o } \\
\text { owth rate, } \\
\text { additiona }\end{array}$ & $\begin{array}{l}\text { dependent } \\
\text { le in the cas } \\
\text { used as instr }\end{array}$ & $\begin{array}{l}\text { able. } \\
\text { the ordinal } \\
\text { nts. }\end{array}$ \\
\hline
\end{tabular}

